\title{
KEMATANGAN JIWA BERAGAMA
}

\author{
Mulyono
}

Fakultas Tarbiyah Universitas Islam Negeri (UIN) Malang

Jl. Gajayana 50 Malang 65144 Telp.0341-551354,558882

Faks.0341-572533,0341-558882 e-mail:mulyono_ma@yahoo.com

\section{Abstract}

Human beings have two experiences; a) physical, and b) spiritual. The physical growth is based on the chronological age, then that is known as adultery. Whereas the spiritual growth is based on the capability level, and the top of this growth is known as maturity. The growth level that is achieved by every individual will be different. Anyone can be adult physically, not spiritually. To be adult spiritually, someone may be mature in his/her personality soul. The people's soul is mature when the people's mature soul is interrelated with religiosity that is known as a maturity of religious soul. There are six characteristics of maturity: 1) having a good differentiation, 2) having dynamic motivation in spiritual life, 3) having proper implementation of the religion consistently and productively, 4) having comprehensive point of view, 5) having integrated point of view and 6) having high motivation in finding and serving the God.

Key words: a mature, soul, having religion

\section{Pendahuluan}

Salah satu dari sepuluh kecenderungan era global (Naisbitt dan Abdurdene, 1990: 3) adalah kebangkitan kembali agama. Setelah kurañg 
lebih 200 tahun sejak munculnya Revolusi Industri di Inggris abad ke 18, banyak orang khususnya di wilayah. Barat melupakan agama dan mengagungkan ilmu pengetahuan dan teknologi (iptek). Iptek ternyata tidak banyak membawa kedamaian hidup, maka masyarakat dari pelbagai belahan dunia sadar untuk mengkaji kembali agama-agama setelah mereka tinggalkan beberapa waktu.

Khususnya di Indonesia, paling tidak sejak dekade 1985-an, kita menyaksikan bahwa kehidupan keberagamaan masyarakat telah berkembang begitu pesat, yang seringkali diistilahkan dengan era santrinisasi. Era santrinisasi ini Nurcholish Madjid (1997: 62), dengan meminjam istilah Naisbitt, sebagai Mega Kecenderungan Indonesia, yang prosesnya "telah melaju tanpa bisa dikendalikan oleh siapa pun." Perkembangan kehidupan agama tersebut dapat kita saksikan secara kasat mata, mulai dari menjamurnya tempat-tempat ibadah serta lembaga-lembaga sosial keagamaan di pelbagai sudut kampung dan kawasan, ramainya sholat Jum'at dan Tarwih, bergaungnya pembacaan ayat-ayat suci al-Qur'an setiap saat, banyaknya wanita menggunakan jilbab, padatnya jamaah majelis-majelis taklim, pengajian dan istighasah akbar serta kajian-kajian ke-Islaman yang begitu marak di media elektronik maupun media cetak serta terus meningkatnya jumlah jamaah haji setiap tahun. Apabila dinilai secara kuantitas, maka kita akan cepat menyimpulkan bahwa perkembangan kehidupan agama di Indonesia mengalami perkembangan yang luar biasa, dan boleh jadi perkembangan ini tidak bisa dibendung oleh siapapun maupun melalui kekuatan apapun. Kita dapat berasumsi bahwa perkembangan kehidupan agama (Islam) di Indonesia saat ini adalah perkembangan terbesar dalam sepanjang sejarah Islam masuk ke Nusantara, yang melebihi perkembangan Islam pada abad 13 sampai dengan 16 Masehi di saat kejayaan kerajaan-kerajaan Islam.

Namun ironisnya, pada saat yang sama pula, kita juga menyaksikan perilaku-perilaku masyarakat yang menyimpang dari ajaran agama yang diyakininya. Ungkapan ini mudah saja kita buktikan dalam kehidupan nyata, dimana kita setiap saat juga menyaksikan tindakan tak terpuji mulai 
dari kenakalan anak-anak dan remaja seperti tawuran antar geng, penggunaan narkoba yang sudah merambah di semua lini masyarakat, korupsi, kolusi, perselingkuhan, seks bebas, pencurian, pemerkosaan, perusakan lingkungan alam, merajalelanya praktik-praktik perdukunan dan klenik serta semakin ramainya pula tempat-tempat yang dimitoskan.

Pertanyaannya adalah, bagaimana pengaruh kehidupan agama terhadap perilaku sehari-hari kehidupan masyarakat atau seseorang? Mengapa orang beramai-ramai mendatangi tempat ibadah dan pada saat yang sama melanggar ajaran agama? Apakah kehidupan agama kita belun: matang? Bagaimana seseorang bisa disebut telah memiliki kematangan jiwa agama? Apa ciri-ciri orang yang disebut memiliki kematangan jiwa agama? Terkait dengan pertanyaan tentang kematangan jiwa beragama tersebut, tulisan ini ingin menjawabnya dalam perspektif psikologi agama.

\section{Kriteria Orang yang Matang Beragama}

Menurut penelitian Allport (1967), bahwa ada enam ciri-ciri sentimen beragama yang matang, yaitu adanya differensiasi, dinamis, produktif, komprehensif, integral, dan keikhlasan dalam pengabdian kepada Tuhan. Berdasarkan pendapat Allport tersebut, maka dapat dikembangkan bahwa karakteristik orang yang telah matang jiwa beragamanya, adalah jika seseorang memiliki enam kriteria, yaitu: (1) differensiasi yang baik, (2) motivasi kehidupan beragama yang dinamis, (3) pelaksanaan ajaran agama secara konsisten dan produktif, (4) pandangan hidup yang komprehensif, (5) pandangan hidup yang integral, (6) semangat pencarian dan pengabdian kepada Tuhan (Aziz, 1991: 50). Hal itu dapat dijelaskan sebagai berikut:

\section{a. Differensiasi yang Baik}

Differensiasi berarti semakin bercabang, makin bervariasi, makin kaya dan makin majemuk suatu aspek psikis yang dimiliki seseorang. Semua pengalaman, rasa dan kehidupan beragama makin lama semakin matang, semakin kaya, kompleks dan makin bersifat pribadi. Pemikirannya makin 
kritis dalam memecahkan pelbagai permasalahan yang dihadapi berlandaskan ke-Tuhanan. Penghayatan yang berhubungan dengan Tuhan makin dirasakan bervariasi dalam pelbagai suasana dan nuansa. Dalam kesendiriannya; ia mencari dan merasakan kerinduan kepada Tuhan. Perasaan, penghayatan, pemikiran, kemauan dan keinginan yang bergolak pada situasi dan kondisi yang berbeda tersebut merupakan differensiasi kesadaran beragama. Harapan akan surga dan keridhaan Tuhan, kecemasan dan ketakutan terhadap api neraka dan siksaan Tuhan, cinta kasih terhadap sesama pemeluk agama serta kebencian terhadap hawa nafsu dan godaan syetan, kesemuanya itu merupakan hasil differensiasi kesadaran beragama yang terpolakan ke dalam suatu sistem mental.

Kesadaran beragama yang terdifferensiasi merupakan perkembangan tumbuhnya cabang-cabang baru dari pemikiran kritis, alam perasaan dan motivasi terhadap pelbagai rangsangan lingkungan serta terjadinya reorganisasi yang terus- menerus. Mulai dari peniruan dan identifikasi terhadap kehidupan Rasulullah saw. Sebagai uswah hasanah, meneladani kesantunan orangtua maupun kehebatan tokoh agama yang diidolakan, sosialisasi dengan masyarakat sekitarnya, timbulnya pemikiran-pemikiran dan pengolahan sendiri melalui pengalaman keagamaan, akhirnya bercabang dan beranting menjadi kesadaran beragama yang kaya dan rimbun.

Kesadaran beragama yang tidak terdifferensiasi menunjukkan sikap dan tingkah laku keagamaan yang tidak kritis, statis dan menerima nasib. Ia menerima ajaran agama tanpa pengolahan serta mempercayai begitu saja, apa yang diutarakan oleh guru maupun tokoh agama. Ia merasa puas terhadap keimanan yang dimilikinya. Kesadaran beragama yang tidak terdifferensiasi nampak sederhana, miskin wawasan, kurang kritis, kurang dinamis dan kurang terintegrasi di dalam kepribadiannya. Sikapnya bersifat reảktif, tidak lentur, mudah terbawa arus atau masa bodoh terhadap situasi sosial politik kemasyarakatan dan perubahan lingkungan. Seringkali nampak adanya kebencian, dengki, hasud, iri hati, kecemasan, prasangka terhadap suku dan agama lain sebagai akibat tidak tersalurkan atau penekanan konflik 
batin ke alam bawah sadar serta tidalc terolahnya permasalahan, pertentangan dan perbedaan paham yang dijunupai dalam kehidupan seharihari. Sebaliknya, kesadaran beragama yang terdiffcrensiasi menunjukkan sikap dan tingkah laku yang kaya, matang, kritis dan fleksibel sebagai warna dari pengalaman keagamaan yang semakin luas.

\section{b. Motivasi Kehidupan Beragama yang Dinamis}

Dari sudut psikologi, motivasi kehidupan beragama pada mulanyã berasal dari pelbagai dorongan, baik biologis, psikis maupun sosial. :, Dorongan biologis, seperti rasa lapar, rasa haus, kemiskinan, penderitaan, penjajahan dan penindasan. Orang akan termotivasi mendekatkan diri kepada Tuhan saat dilanda kekurangan, kemiskinan, bencana alam, sákit atau penderitaan lainnya. Dalam al-Kitab maupun al-Qur'an secara implisit diterangkan bahwa Bani Israel akan taat mengikuti perintah-perintah Nabi maupun Tuhan di saat di landa krisis maupun ditindas bangsa lain seperti bangsa Falistin dan Babilonia. Sebaliknya, kalau mereka sudah terbebaskan dari penindasan maupun hidup dalam kemakmuran, watak Bani Israel akan muncul yaitu suka membakang terhadap ajaran para nabinya bahkan berusaha membunuhnya (wa yaqtulu al-anbiya'), seperti yang menimpa Nabi Zakaria, as. dan putranya, Yahya, as. Dalam realitas sekarang bangsa-bangsa yang sering mengalami krisis ekonomi maupun politik ada kecenderungan aktif melakukan pendekatan kepada Tuhan, seperti yang terjadi di Indonesia di kala awal krisis di mana-mana kita dapatkan kegiatan seperti taubat dan doa bersama (istighasah akbar), tetapi ketika krisis mulai mereda kegiatan semacam itu seakan hilang gaungnya. Inilah watak asli manusia, dia akan dekat kepada Tuhan saat dilanda berbagai bencana dan menjauhkan dari Tuhan ketika kemakmuran telah datang sebagaimana yang dijelaskan dalam al-Qur'an Surat Saba' yaitu kejadian bencana banjir (sailul 'arim) yang melanda negeri Saba' (Yaman). Sifat manusia tersebut dinyatakan dalam al-Qur'an: 


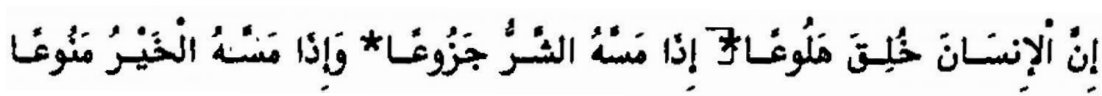

"Sesungguhnya manusia diciptakan bersifat keluh kesah lagi kikir. Apabila ia ditimpa kesusahan ia berkeluh kesah. Dan apabila ia mendapat kebaikan ia amat kikir." (QS. al-Ma'arij: 19-21).

Dorongan psikologis, seperti kebutuhan akan kasih sayang, pengembangan diri, rasa ingin tahu, harga diri dan sebagainya. Dalam realitas kehidupan beragama, sering ditemukan banyak pemuda-pemudi aktif mendekatkan diri kepada Tuhan dikala memiliki pengharapan jatuh cinta pada lawan jenisnya, atau mereka mengharapkan agar Tuhan memberikan jodoh yang baik. Banyak hasil observasi menunjukkan bahwa para pelajar maupun mahasiswa akan lebih disiplin beribadah di saat-saat mendekati ujian, tetapi mereka akan mengurangi bahkan melupakannya di saat ujian sudah berlalu. Demikian juga untuk memenuhi kebutuhan-kebutuhan psikologis yang lain. Hal ini nampaknya memang sudah menjadi tabiat manusia, yang juga dikisahkan dalam Al-Kitab-Pejjanjian Lama, yaitu bagaimana semangatnya Ya'kub (muda) dalam bekerja maupun berbuat kebajikan di rumah pamannya, Laban di Mesopotamia, selama 20 tahun. Selama tujuh tahun, dia melewati hari-harinya begitu indah dan penuh vitalitas karena didorong oleh rasa cinta kepada anak gadis pamannya yang pertama bemama Lea (kemudian menjadi ibu Yahudi bersaudara), serta harus menambah tujuh tahun bekerja lagi dengan dinikahkan anak kedua pamannya yang bernama Rahel (kemudian menjadi ibu dari Yusuf dan Benyamin) serta bekerja 6 tahun lagi untuk mendapatkan upah berupa bagian domba (Kitab Kejadian, 29). Kebutuhan psikologis telah menjadi motif seseorang untuk meningkatkan semangat pendekatan diri kepada Tuhan seperti yang dicontohkan Ya'kub muda sekalipun calon nabi dan rasul.

Kebutuhan sosial, seperti ingin populer, agar diterima oleh suatu kelompok maupun ambisi pribadi akan kebutuhan kekuasaan juga seringkali menjadi motif seseorang ataupun kelompok lebih intens melakukan kehidupan beragama. Banyak ditemukan di lapangan, bahwa karena 
terdorong oleh ambisi-ambisi pribadi, seseorang aktif melakukan kegiatan sosial keagamaan di masyarakat seperti menjadi takmir masjid atau membangun madrasah dan panti asuhan. Agar diterima di lingkungannya yang bernuansa agamis, tak sedikit orang aktif mengikuti kegiatan keagamaan seperti tahlil/yasin walaupun dalam kehidupan sehari-hari tak pernah shalat. Dalam banyak observasi ditemukan bahwa orang-orang termotivasi untuk aktif menjadi pengurus suatu organisasi keagamaan dari tingkat ranting hingga pusat sebagai sarana mendapatkan kekuasaan yang lebih formal. Dalam kasus ini seringkali organisasi agama dijadikan tangg: mendapatkan kekuasaan. Dan tentunya masih banyak lagi berbagai kebutuhan dan kepentingan manusia menjadi motifmelakukan kehidıpan beragama secara lebih intens.

Kebutuhan-kebutuhan tersebut jika mendapat pemuasan dalam kehidupan beragama dapat menimbulkan dan memperkuat motivasi keagamaan yang lama-kelamaan akan menjadi otonom (mandiri), yaitu orang akan termotivasi untuk beribadah, baik didorong oleh kebutuhan atau tidak. Derajat otonom dalam bahasa agama sering disebut beribadah yang dilandasi niat "ikhlas" yang artinya "murni" beribadah karena ingin melaksanakan kewajiban sebagai seorang hamba yang baik serta hanya mengharapan ridha-Nya. Derajat kekuatan motif beragama itu sedikit banyak dipengaruhi oleh pemuasan yang diberikan oleh agama, makin kokoh dan makin otonom motif tersebut. Akhimya merupakan motif yang berdiri sendiri dan secara konsisten serta dinamis mendorong manusia untuk bertingkah laku keagamaan. Salah satu perbedaan penting antara orang yang memiliki kesadaran beragama yang matang dengan orang yang belum matang terletak pada derajat otonomi motivasi keagamaannya.

Bila kesadaran beragama telah menjadi pusat sistem mental kepribadian yang mantap, maka ia akan mendorong, mempengaruhi, mengarahkan, mengolah serta mewarnai semua sikap dan tingkah laku seseorang. Peranan kesadaran beragama itu merasuk ke dalam aspek mental lainnya. Tanggapan, pengamatan, pemikiran, perasaan dan sikapnya akan diwarnai oleh rasa keagamaan. Keindahan alam, kicau burung, proses pemekaran bunga-bungà, 
tumbuhnya biji-bijian, kehebatan larinya kuda, tabiat unta, keperkasaan gunung-gunung, perputaran bumi, bintang dan matahari, kecepatan aliran listrik dan gelombang elektromagnetik, proses terjadinya susu, perkembangan bayi, perkembangan jiwa dari fase ke fase, kematian seseorang, bekerjanya otak, nilai-nilai kemasyarakatan, anekaragamnya warna kulit bahasa seni dan budaya, sejarah bangsa-bangsa dan semua fakta akan diamati, dipelajari, diselidiki, dihayati, dipahami dan dinikmati melalui wama agama.

Dinamika rasa keagamaan yang matang bergantung pada seberapa jauh kesadaran beragama menjadi sistem mental di antara berbagai sistem kejiwaan yang membentuk kepribadian seseorang. Semakin matangnya motivasi beragama yang terus mengalami perkembangan tersebut sebagaimana dijelaskan firman Allah berikut:

"Sesungguhnya aku menghadapkan diriku kepada Dzat yang menciptakan langit dan bumi, dengan cenderung kepada agama yang benar, dan aku bukanlah termasuk orang-orang yang mempersekutukan Tuhan". (QS. al-An'am: 79).

"Katakanlah: Sesungguhnya sembahyangku, ibadatku, hidupku dan matiku hanyalah untuk Allah, Tuhan semesta alam. Tiada sekutu bagiNya; dan demikian Itulah yang diperintahkan kepadaku dan Aku adalah orang yang pertama-tama menyerahkan diri (kepada Allah)". (QS. al-An'am: 162-163).

\section{c. Pelaksanaan Ajaran Agama Secara Konsisten dan Produktif}

Tanda ketiga kesadaran beragama yang matang terletak pada konsistensi atau keajegan pelaksanaan hidup beragama secara bertanggung jawab dengan mengerjakan perintah agama sesuai kemampuan dan berusaha secara maksimal meninggalkan larangan-larangan-Nya. Pelaksanaan kehidupan beragama atau peribadatan merupakan realisasi penghayatan ke-Tuhanan dan keimanan. Pengertian ibadah mencakup pelaksanaan aturan, hukum, ketentuan, tata cara, perintah, kewajiban, dan larangan dalam hubungannya dengan Tuhan, manusia, masyarakat, dan alam. Ibadah 
yang menekankan realisasi hubungan manusia dengan Tuhan, sering disebiut ibadah dalam arti khusus. Formalitas, tata cara dan peraturan ibadah khusus telah ditentukan oleh Tuhan melalui wahyu yang disampaikan kepada Nabi sehingga tidak boleh diubah atau dimodifikasikan. Ibadah dalam arti luas mencakup seluruh kehendak, cita-cita, sikap, dan tingkah laku manusia berdasarkan penghayatan ke-Tuhanan disertai niat atau kesengajaan dengan ikhlas karena dan demi Allah. Orang yang memiliki kesadaran beragama yang matang akan melaksanakan ibadahnya dengan konsisten, stabil, mantap dan penuh tanggung jawab dan dilandasi warna pandangan agame yang luas. Tiada kebahagiaan yang lebih mulia daripada kewajiban melaksanakan perintah agama secara konsisten (istigamah).

Bagi orang yang belum matang seringkali muncul gejolak yang kuat untuk melaksanakan ibadahnya, namun kurang konsisten dan kurang terintegrasi dengan perilaku keagamaan lainnya, misalnya kadang-kadang gejolak ibadahnya karena dipengaruhi oleh orang lain. Ia melaksanakan ibadah dan mengendalikan kehidupan moralnya secara kaku, kadangkadang terlalu berlebihan mengharapkan bahkan memaksa orang lain agar beribadah dan bermoral seperti dirinya. Orang yang tidak melaksanakan ibadah sebagaimana ia sendiri melaksanakannya akan dimusuhi. Sikap demikian dapat disebut sok-agamis, sok moralis. Ada pula orang yang hanya tekun melaksanakan ibadah secara parsial atau sporadis seperti melaksanakan puasa sunnah berbulan-bulan tanpa shalat atau suka berderma akan tetapi tidak pernah mengeluarkan zakat. Mereka yang belum matang kesadaran beragamanya menunjukkan tingkah laku keagamaan yang kaku, labil, dan kurang disertai rasa tanggung jawab.

Dalam melaksanakan hubungan dengan Tuhan, orang yang memiliki kesadaran beragama yang matang benar-benar menghayati hubungan tersebut dan tiap kali terjadi penghayatan baru. Ibadahnya bersifat subyektif, kreatif dan dinamis. Ia selalu berusaha mengharmoniskan hubungannya dengan Tuhan, manusia lain dan alam sekitarnya melalui sikap dan tingkah lakunya. Sikap dan tingkah laku itu adalah perilaku moralitas agama. 
Kehidupan beragama dengan perilaku bermoral tidak dapat dipisahkan. Kehidupan bermoral adalah sikap dan tingkah laku yang baik, sedangkan tujuan agama yang penting adalah membentuk manusia bermoral atau berakhlak mulia. Hampir semua kehidupan bermoral dalam masyarakat berasal dari moralitas agama. Norma atau ukuran etika tidak mungkin dapat tumbuh tanpa idealisme, sedangkan idealisme tidak mungkin berkembang tanpa kehidupan rohaniah dan ke-Tuhanan.

Dapatkah manusia menetapkan norma-norma moral atau hukum bermasyarakat tanpa norma agama? Dapatkah para ahli hukum menentukan definisi "hukum" atau "keadilan" tanpa menghubungkannya dengan agama dan Tuhan? Seorang ahli hukum berkata: "Kalau Anda meminta sepuluh ahli hukum untuk mendefinisikan "hukum", maka bersiap-siaplah Anda untuk mendengarkan sebelas jawaban". Hukum di negara tak ber-Tuhan akan sama pengertiannya dengan pendapat John Austin (1861) dalam Aziz (1991:55), yang mengatakan bahwa hukum ialah suatu aturan yang dikeluarkan oleh seseorang yang mempunyai kedudukan politik lebih tinggi bagi orang yang lebih rendah kedudukan politiknya. Kalau dikatakan bahwa tujuan hukum yang prinsipil ialah untuk mencari "keadilan" maka pertanyaan yang timbul ialah: "Apakah keadilan itu?" Mungkinkah kita melaksanakan "demokrasi" atau "keadilan sosial" tanpa Jijiwai oleh rasa ke-Tuhanan? Memang manusia tidak mampu menciptakan norma-norma hukum dan moral tanpa melibatkan agama atau wahyu Tuhan. Hampir semua pengadilan mengambil sumpah terhadap para saksi berdasarkan agama. Bahkan dalam setiap ketetapan MPR RI selalu didahului kalimat "Dengan Rahmat Tuhan Yang Maha Esa".

Kalau norma agama menjadi landasan moral dan hukum, apakah tidak menimbulkan fanatisme sempit dan kaku? Sama sekali tidak! Norma agama yang berhubungan dengan kehidupan bermasyarakat, bernegara dan berbangsa sangat fleksibel, karena norma agama itu lebih merupakan prinsip umum yang penafsirannya dapat disesuaikan dengan perkembangan zaman dan keadaan setempat. Bagi orang yang memiliki kesadaran beragama yang matang, perubahan zaman merupakan tantangan untuk mengadakan re- 
evaluasi, memodivikasi dan mengolah norma agama yang telah menjadi bagian dari kepribadiannya. Perkembangan ilmu pengetahuan dan teknologi yang pesat dapat menghasilkan pandangan baru yang berbeda dengan hati nuraninya, sehingga menimbulkan pergumulan dan pengolahan serta semangat baru untuk mencari penafsiran dan norma baru dari ajaran agama. Kematangan kesadaran beragama akan mendinamisasikan semangat hidup bermoral, menghasilkan norma baru dan mengarahkan tujuan hidup pada pembangunan dan kesejahteraan umat manusia. Orang-orang yang melaksanakan ajaran agama secara konsisten dan produktif tersebut sebagaimana dijelaskan al-Qur'an, sebagai berikut:

"Sesungguhnya orang-orang yang mengatakan: "Tuhan kami ialah Allah" Kemudian mereka meneguhkan pendirian mereka, maka malaikat akan turun kepada mereka dengan mengatakan: "Janganlah kamu takut dan janganlah merasa sedih; dan gembirakanlah mereka dengan surga yang telah dijanjikan Allah kepadamu". (QS. Fushshilat: 30).

\section{d. Pandangan Hidup yang Komprehensif}

Kepribadian yang matang memiliki filsafat hidup yang utuh dan komprehensif. Keanekaragaman kehidupan dunia harus diarahkan pada keteraturan. Keteraturan ini berasal dari analisis terhadap fakta yang ternyata mempunyai hubungan satu sama lain. Fakta yang perlu dicari kaidahnya itu bukan hanya benda materi, akan tetapi keteraturan itu meliputi pula alam perasaan, pemikiran, motivasi, norma, nilai-nilai kemasyarakatan dan nilai-nilai kehidupan rohaniah. Manusia memerlukan pegangan agar dapat menentukan pilihan tingkah lakunya secara pasti.

Agama seperti juga filsafat mampu memberikan jawaban, keteraturan dan hukum/kaidah secara rasional dan logis. Bahkan agama lebih luas dan lebih mendalam daripada filsafat, karena agama tidak hanya memberikan pegangan hidup yang logik dan rasional saja, akan tetapi memberikan pula dinamika penyaluran dan kepuasan bagi dorongan emosional. Agama memberikan jawaban terhadap masalah kematian, hidup sesudah mati, alam 
akhirat dan rasa ke-Tuhanan. Agama memberikan dorongan dan motivasi lebih kuat dan lebih bermakna terhadap semangat dan arti hidup.

Bagi orang yang matang beragamanya, maka memahami dan melakukan agama tidak sekedar bersifat formalitas dan parsial, tetapi berusaha memahami dan melaksanakan agama secara logika, perasaan dan tindakan. Bahkan memasuki wilayah agama secara utuh. $\mathrm{Hal}$ itu sebagaimana difirmankan Allah swt. berikut:

"Hai orang-orang yang beriman, masuklah kamu ke dalam Islam keseluruhan, dan janganlah kamu turut langkah-langkah syaitan. Sesungguhnya syaitan itu musuh yang nyata bagimu". (QS. alBaqarah: 208).

\section{e. Pandangan Hidup Yang Integral}

Kesadaran beragama yang matang ditandai adanya pandangan hidup yang komprehensif yang dapat mengarahkan dan menyelesaikan berbagai permasalahan hidup. Filsafat hidup yang komprehensif itu meliputi berbagai pola pandangan, pemikiran dan perasaan yang luas. Di samping komprehensif, pandangan dan pegangan hidup itu harus terintegrasi, yakni merupakan suatu landasan hidup yang menyatukan hasil differensiasi aspek kejiwaan yang meliputi fungsi kognitif, afektif dan psikomotorik. Dalam kesadaran beragama, integrasi tercermin pada keutuhan pelaksanaan ajaran agama, yaitu keterpaduan antara Islam (amal shaleh), keimanan (keyakinan dan pemikiran) serta ihsan (perasaan/kalbu). Pandangan hidup yang matang bukan hanya keluasan cakupannya saja, akan tetapi mempunyai landasan terpadu yang kuat dan harmonis (Aziz, 1991: 58).

Pegangan hidup keagamaan yang komprehensif dan terintegrasi dengan harmonis bukan hanya mampu menghadapi permasalahan hidup empat belas abad yang lalu ketika Nabi saw terakhir diturunkan, akan tetapi dapat menjadi pegangan bagi manusia yang hidup pada masa kini yang ditandai kepesatan perkembangan sains dan teknologi. Norma serta hasil penemuan sains dan teknologi dapat bertentangan dengan penafsiran norma kepercayaan dar kebiasaan perilaku keagamaan. Orang yang memiliki 
kesadaran beragama yang terintegrasi akan berusaha mengolah pertentangan itu dengan menganalisis kembali penafsiran ajaran agama dan meneliti norma penemuan baru dengan kritis, sehingga menghasilkan pandangan baru yang dapat dijadikan pegangan. Ia menyadari, bahwa pada dasarnya agama dan sains tidaklah bertentangan, bahkan harus bekerja sama dan saling mendukung, karena keduanya sama-sama mencari kebenaran.

Pandangan orang yang matang jiwa beragamanya akan terbuka lebar dan berusaha mencari, menafsirkan dan menemukan nilai-nilai baru ajaran agamanya agar dapat direalisasikan dalam kehidupan sehari-hari sesuai perkembangan zaman. Dalam pencarian penafsiran-penafsiran baru setiap orang akan memandang permasalahan sesuai dengan tingkat kematangan kesadaran beragama yang dimilikinya. Tiap-tiap orang memiliki kematangan kesadaran beragama berbeda, karena perbedaan pengalaman hidup. Akibatnya, penghayatan dan perasaan ke-Tuhanan, keimanan dan peribadatannya bersifat subyektif dan pribadi. Walaupun keimanan dan peribadatan bagiorangyang matang beragama bersifat pribadi dan subyektif secara sosial keagamaan ia tetap senang hati bergabung dengan orang-orang yang taat beragama di sekitarnya tanpa memamerkan kelebihannya di muka umum (Syarif, 2003: 50-53).

Tentang kematangan jiwa beragama seseorang yang didorong oleh pandangan hidup yang integral tersebut sebagaimana termaktub dalam alQur'an Surat al-Fajr sebagai berikut:

"Hai jiwa yang tenang, kembalilah kepada Tuhanmu dengan hati yang puas lagi diridhoi-Nya. Maka masuklah ke dalam jama'ah hambahamba-Ku dan masuklah ke dalam surga-Ku". (QS. al-Fajr: 27-30).

\section{f. Semangat Pencarian dan Pengabdian kepada Tuhan}

Ciri terakhir dari orang yang memiliki kesadaran beragama yang matang ialah adanya semangat mencari kebenaran, keimanan, rasa ke-Tuhanan dan cara-cara terbaik untuk berhubungan dengan manusia dan alam sekitar. Ia selalu menguji keimanannya melalui pengalaman-pengalaman keagamaan sehingga menemukan keyakinan lebih tepat. Peribadatannya 
selalu dievaluasi dan ditingkatkan agar menemukan keledzatan ibadah dan kesyahduan penghayatan "kehadiran" Tuhan. Walaupun demikian ia masih merasakan bahwa keimanan dan peribadatannya, belum sebagaimana mestinya dan belum sempurna (Aziz, 1991: 59).

Gambaran tentang Tuhan tiap kali dirasakan masih merupakan suatu hipotesis hasil pemikiran yang tidak terlepas dari orientasi ruang dan waktu. Gambaran itu tiap kali bukanlah Tuhan sebenarnya. Ia berusaha terus mencari dan mendapatkan keimanan yang lebih tepat. Keimanan yang lebih tepat pun ternyata belum mencapai kebenaran yang sempurna. Kesempurnaan itu sendiri tidak mungkin dicapai seumur hidupnya. Ia hanya mampu mendekatinya. Setiap beribadah ia merasa dekat dengan Tuhan. Kedekatan itu demikian dekat sehingga lebih dekat daripada urat nadi di lehernya. Bahkan akhirnya kedekatan itu tidak dapat digambarkan dengan kata-kata kepada orang lain. Hal itu sebagaimana yang digambarkan kisah Ibrahim as. dalam mencari Tuhan-Nya. Setelah Ibrahim dalam perjuangan panjangnya menemukan hakikat Tuhan yang sejati; maka jiwa ke-Tuhanannya tak pernah lepas dari kepribadiannya, bahkan ke manapun pergi ia merasa selalu dekat dengan Tuhan hingga mendapat gelar Ibrahim Khalilullah (Ibrahim Sahabat Allah).

Orang yang memiliki jiwa beragama yang matang, meyakini sepenuhnya akan keberadaan Tuhan, walaupun kedudukan Tuhan berada pada wilayah "adoh tanpo wewangenan - cedak canpo sesenggolan" (meminjam istilah para penganut aliran kebatinan Jawa), yaitu Tuhan dirasakan berada pada wilayah yang amat jauh yang tak terjangkau sekaligus dekat sekali tetapi tidak pernah bersentuhan. Namun bagi orang yang matang jiwa agamanya, akan berusaha baik secara logika maupun kalbu untuk menghayati akan "kedekatan" dan "kehadiran Tuhan" setiap saat.

Dengan demikian ciri dari orang yang matang beragama adalah setiap nafas, setiap langkah dan aktivitasnya selalu diupayakan untuk mendekatkan diri kepada-Nya serta untuk mencari ridha-Nya dengan sesegera mungkin. Hal itu sebagaimana dijelaskan dalam beberapa ayat al-Qur'an berikut: 
"Dan bersegeralah kamu kepada ampunan dari Tuhanmu dan kepada surga yang luasnya seluas langit dan bumi yang disediakan untuk orang-orang yang bertakwa. (Yaitu) Orang-orang yang menafkahkan (hartanya), baik di waktu lapang maupun sempit, dan orang-orang yang menahan amarahnya dan mema'afkan (kesalahan) orang. Allah menyukai orang-orang yang berbuat kebajikan". (QS. al-Imran: 133134).

\section{Kematangan Beragama Menurut Al-Qur'an}

- Di dalam al-Qur'an terdapat beberapa kriteria orang yang bisa dikategorikan matang agamanya antara lain: 1) Orang tersebut amat cinta kepada Allah (QS. al-Baqarah: 165); 2) Beriman kepada semua nabi (QS. al-Baqarah: 136); 3). Mereka senantiasa bersama Allah dan tidak pernah cerai berai dari pada-Nya, iman mereka mantap, tujuan hidupnya menegakkan tauhid, dengan senantiasa mengabdi dan beribadah kepadaNya (QS. al-Baqarah: 194); 4). Mereka juga orang yang selalu setia pada janji (QS. al-Baqarah: 177); 5). Selalu bantu membantu dalam kebajikan dan bukan dalam hal kejahatan (QS. al-Maidah: 2); 6) Bersikap adil walaupun harus merugikan dirinya dan golongannya (QS. an-Nisa: 135); 7) Bersikap jujur sekalipun pada lawan (QS. al-Maidah: 2); 8) Hidup secara wajar (QS. al-Baqarah: 62); 9) Orang yang selalu menafkahkan sebagian hartanya baik dalam kondisi lapang maupun sempit serta memaafkan kesalahan orang lain (QS. al-Imran: 133-134); 10) Hidupnya dikorbankan demi mencari ridha Allah swt. (QS. al-Baqarah: 207). Dan tentunya masih banyak lagi ayat-ayat al-Qur'an maupun hadits yang menjelaskan tentang kematangan beragama seorang muslim.

\section{Simpulan}

Berkembang pesatnya kehidupan beragama masyarakat Indonesia saat ini kalau dilihat dari teori kematangan jiwa beragama bisa dikatakan masih bersifat euforia atau trend menurut istilah Naisbitt, tak jauh bedanya dengan trend global lainnya seperti: fashion, food dan fun (hiburan, rekreasi, olahraga 
dan seks). Juga masih bersifat kecenderungan zaman sebagaimana beberapa kecenderungan zaman yang sudah diramalkan oleh Naisbit tersebut.

Dengan demikian masih membutuhkan pembinaan secara berkesinambungan oleh pelbagai pihak, dengan pendekatan dan metode yang sesuai untuk menuju pada jiwa keagamaan masyarakat yang semakin matang. Sehingga dengan kematangan jiwa beragama diharapkan akan semakin mengurangi jurang pemisah antara euforia kehidupan beragama dengan perilaku individu dan masyarakat yang sesuai dengan nilai-nilai agama yang dianutnya. Sehingga terwujud masyarakat yang agamis secara lahir batin yang memiliki kekokohan aqidah dan kedalaman spritual, keagungan akhlak serta amal shaleh sehingga menjadi warga maupun bangsa yang mendapat ridha-Nya atas ketakwaannya terbut, (baldasun thayyibatun warabbun ghafur).

\section{Daftar Pustaka}

Al-Kitab-Perjanjian Lama, 1986. Jakarta: Lembaga Alkitab Indonesia.

Allport, Gordon W. 1967. The Individual and his Religion. New York: Macmillan Company.

Al-Qur'an dan Terjemahnya. 1977. Jakarta: Departemen Agama RI.

Jalaluddin, 2004. Psikologi Agama. Jakarta: RajaGrafindo Persada.

James, William. 2003. The Varieties of Religious Experience: PengalamanPengalaman Religius. Penerjemah, Luthfi Anshari. Yogyakarta: Jendela, Cetakan I.

Madjid, Nurcholish. 1997. Tradisi: Peran dan Fungsinya dalam Pembangunan di Indonesia. Jakarta: Paramadina.

Naisbitt, John Naisbitt \& Patricia Aburdene. 1990. Megatrends 2000. Terjemah, Drs. Fx. Budijanto. Jakarta: Binarupa Aksara.

Syarif, Adnan. 2003. Psikologi Qur'ani. Bandung: Pustaka Hidayah. 
Thouless, Robert. 1992. Pengantar Psikologi Agama. Jakarta: CV. Rajawali. QS. al-Ma'aarij: 19-21

QS. al-An'am: 79

QS. al-An'am: 162-163

QS. Fushshilat: 30

QS. al-Baqarah: 208

QS. al-Fajr: $27-30$

QS. al-Imran: 133-134 